\title{
The evolution of roommate networks: a comment on Jackson and Watts JET (2002)
}

Citation for published version (APA):

Klaus, B. E., Klijn, F., \& Walzl, M. (2007). The evolution of roommate networks: a comment on Jackson and Watts JET (2002). METEOR, Maastricht University School of Business and Economics. METEOR Research Memorandum No. 012 https://doi.org/10.26481/umamet.2007012

Document status and date:

Published: 01/01/2007

DOI:

10.26481/umamet.2007012

Document Version:

Publisher's PDF, also known as Version of record

\section{Please check the document version of this publication:}

- A submitted manuscript is the version of the article upon submission and before peer-review. There can be important differences between the submitted version and the official published version of record.

People interested in the research are advised to contact the author for the final version of the publication, or visit the DOI to the publisher's website.

- The final author version and the galley proof are versions of the publication after peer review.

- The final published version features the final layout of the paper including the volume, issue and page numbers.

Link to publication

\footnotetext{
General rights rights.

- You may freely distribute the URL identifying the publication in the public portal. please follow below link for the End User Agreement:

www.umlib.nl/taverne-license

Take down policy

If you believe that this document breaches copyright please contact us at:

repository@maastrichtuniversity.nl

providing details and we will investigate your claim.
}

Copyright and moral rights for the publications made accessible in the public portal are retained by the authors and/or other copyright owners and it is a condition of accessing publications that users recognise and abide by the legal requirements associated with these

- Users may download and print one copy of any publication from the public portal for the purpose of private study or research.

- You may not further distribute the material or use it for any profit-making activity or commercial gain

If the publication is distributed under the terms of Article $25 \mathrm{fa}$ of the Dutch Copyright Act, indicated by the "Taverne" license above, 
Bettina Klaus, Flip Klijn, Markus Walzl

The Evolution of Roommate Networks:

A Comment on Jackson and Watts JET (2002)

$\mathrm{RM} / 07 / 012$

JEL code: C62, C78

\section{METE@R}

Maastricht research school of Economics of TEchnology and ORganizations

Universiteit Maastricht

Faculty of Economics and Business Administration P.O. Box 616

NL - 6200 MD Maastricht

phone : ++31433883830

fax $\quad$ : ++31433884873 



\title{
The Evolution of Roommate Networks: A Comment on Jackson and Watts JET (2002)*
}

\author{
Bettina Klaus, ${ }^{\dagger}$ Flip Klijn, ${ }^{\ddagger}$ and Markus $W a l z l^{\S}$
}

April 2007

\begin{abstract}
We extend Jackson and Watts's (2002) result on the coincidence of S-stochastically stable and core stable networks from marriage problems to roommate problems. In particular, we show that the existence of a side-optimal core stable network, on which the proof of Jackson and Watts (2002, Theorem 2) hinges, is not crucial for their result.
\end{abstract}

JEL classification: $\mathrm{C} 62, \mathrm{C} 78$.

Keywords: Core, networks, roommate problems, stochastic stability.

\section{Introduction}

Jackson and Watts (2002), from now on JW, model network formation as a dynamic process in which individuals form and sever links based on the improvement that the resulting network offers them relative to the current network. JW's contribution is twofold. First, they introduce and characterize a dynamic solution concept for networks - stochastic stability. Second, for marriage problems (Gale and Shapley, 1962) they show that the set of S-stochastically stable networks coincides with the set of core stable networks (JW, Theorem 2).

In their seminal paper, Gale and Shapley (1962) also generalize (two-sided) marriage problems to (one-sided) roommate problems. ${ }^{1}$

Two features of the core (the set of core stable networks in JW's terminology) do not extend from marriage to roommate problems. First, not every roommate problem is solvable, i.e., a

${ }^{*}$ The authors are grateful to the Netherlands Organisation for Scientific Research (NWO) and the Maastricht Research School of Economics of Technology and Organizations (METEOR) for financial support. F. Klijn thanks the Department of Economics of Maastricht University for its hospitality. F. Klijn's research was also supported through the Spanish Plan Nacional I+D+I (SEJ2005-01690) and the Generalitat de Catalunya (SGR2005-00626 and the Barcelona Economics Program of XREA).

${ }^{\dagger}$ Corresponding author: Department of Economics, Maastricht University, P.O. Box 616, 6200 MD Maastricht, The Netherlands; e-mail: b.klaus@algec.unimaas.nl

${ }^{\ddagger}$ Institute for Economic Analysis (CSIC), Campus UAB, 08193 Bellaterra (Barcelona), Spain; e-mail: flip.klijn@iae.csic.es

${ }^{\S}$ Department of Economics, Maastricht University, P.O. Box 616, 6200 MD Maastricht, The Netherlands; e-mail: m.walzl@algec.unimaas.nl

${ }^{1}$ There is a large literature on the marriage problem; see, for instance, Roth and Sotomayor (1990) and the two-sided matching bibliography on Al Roth's game theory, experimental economics, and market design page. In comparison relatively few papers and books deal with roommate problems; some of the key references concerning roommate problems are Chung (2000); Diamantoudi et al. (2004); Gusfield and Irving (1989); Tan (1991). 
core stable network does not always exist. Second, while in marriage problems side-optimal core stable networks always exist and play a crucial role (e.g., in JW's proof of Theorem 2), no similarly prominent core stable networks exist for solvable roommate problems.

Our contribution has two dimensions. First, we extend JW's Theorem 2 to a larger class of network problems (from marriage to roommate problems). ${ }^{2}$ Second, we provide a short proof that does not use the existence of side-optimal core stable networks, on which the proof of JW hinges. In particular, JW's result is not a consequence of the "polarization structure" of the set of core stable networks for marriage problems (which after all is absent for some roommate problems).

\section{Roommate Networks}

We refer to JW (pp. 270-281) for the notation and definitions related to networks.

In a roommate problem, a set of players $N$ has to be partitioned in pairs (roommates) and singletons. Thus, a network is a roommate network if each player $i \in N$ is linked to at most one other player. Hence, the set of roommate networks is $G=\{g \mid i j \in g$ implies $i k \notin g$ for $k \neq j\}$. For roommate networks the value function is defined by $v(g):=\sum_{i \in N} u_{i}(g)$ and the allocation rule by $Y_{i}(v, g):=u_{i}(g)$, where for each $i \in N, u_{i}: G \rightarrow \mathbb{R}$ only depends on the player to which $i$ is linked (possibly himself). From now on we assume that networks are roommate networks. Core stability, simultaneous improving paths, and S-stochastic stability are defined as in JW (pp. 282-285). A roommate problem is solvable if the set of core stable networks is non empty.

Theorem 1. Consider any solvable roommate problem with strict preferences. Then, the set of S-stochastically stable networks coincides with the set of core stable networks.

Proof: Let $g^{\prime}$ be a core stable network. Given a network $g$, let $n\left(g, g^{\prime}\right)$ denote the number of links and single players that are common to $g$ and $g^{\prime}$. Interpreting $n(\cdot, \cdot)$ as distance measure we say $g_{1}$ is closer to $g^{\prime}$ than $g_{2}$ if $n\left(g_{1}, g^{\prime}\right)>n\left(g_{2}, g^{\prime}\right)$.

Diamantoudi et al. (2004, Claim, p. 21) show the following: For any $\tilde{g}$ that is not core stable, there exists a finite simultaneous improving path $\tilde{g}=\tilde{g}_{0}, \ldots, \tilde{g}_{L}$ such that $n\left(\tilde{g}_{L}, g^{\prime}\right) \geq n\left(\tilde{g}, g^{\prime}\right)+1$. Repeated application of Diamantoudi et al.'s (2004) Claim leads to the following result.

Lemma 1. For any non core stable network $\tilde{g}$ there exists a finite simultaneous improving path $\tilde{g}=\tilde{g}_{0}, \ldots, \tilde{g}_{L}=g^{\prime \prime}$ of distinct networks such that $g^{\prime \prime}$ is core stable and $n\left(g^{\prime \prime}, g^{\prime}\right) \geq n\left(\tilde{g}, g^{\prime}\right)+1$.

Claim 1. There exist no closed cycles.

This follows from Lemma 1.

Claim 2. If there is a singleton core stable network, then it is the unique S-stochastically stable network.

This follows from Claim 1.

\footnotetext{
${ }^{2}$ This answers in the affirmative a research question posed by Diamantoudi et al. (2004). They showed that Roth and Vande Vate's (1990) convergence result for marriage problems also holds for solvable roommate problems. Given that JW used Roth and Vande Vate's (1990) convergence result to prove their Theorem 2, Diamantoudi et al. (2004) asked whether the extended convergence result could be used to extend JW's Theorem 2 as well.
} 
Claim 3. If there are $k>1$ core stable networks, then the resistance of any core stable network is $k-1$.

Let $\left\{g_{1}, g_{2}, \ldots, g_{k}\right\}$ denote the set of core stable networks. We prove Claim 3 by constructing a $g_{1}$-tree with resistance $k-1$.

First, we show how to connect the core stable networks $g_{2}, \ldots, g_{k}$ with one mutation each to construct a subtree of the final $g_{1}$-tree. We order core stable networks according to their distance to $g_{1}$ : without loss of generality, $n\left(g_{1}, g_{1}\right)>n\left(g_{2}, g_{1}\right) \geq \ldots \geq n\left(g_{k}, g_{1}\right)$.

Let $\tilde{g}_{2}$ be an adjacent network of $g_{2}$ such that $n\left(\tilde{g}_{2}, g_{1}\right) \geq n\left(g_{2}, g_{1}\right){ }^{3}$ Since $g_{2}$ is core stable and $\tilde{g}_{2}$ is adjacent, $r\left(g_{2}, \tilde{g}_{2}\right)=1$ and $\tilde{g}_{2}$ is non core stable. By Lemma 1 , there exists a finite simultaneous improving path $\hat{p}=\left\{\tilde{g}_{2}, \ldots, \hat{g}\right\}$ of distinct networks such that $\hat{g}$ is core stable and $n\left(\hat{g}, g_{1}\right) \geq n\left(\tilde{g}_{2}, g_{1}\right)+1$. Recall that no core stable network is strictly closer to $g_{1}$ than $g_{2}$. Thus, $\hat{g}=g_{1}$. By definition of $\hat{p}$ the directed path

$$
g_{2}, \underbrace{\tilde{g}_{2}, \ldots, g_{1}}_{\text {path } \hat{p}}
$$

is a $g_{1}$-subtree of resistance 1 that contains $g_{1}$ and $g_{2}$ together with the non core stable networks on path $\hat{p}$.

Let $l \in\{3, \ldots, k\}$ and assume that we have constructed a $g_{1}$-subtree of resistance $l-2$ that contains $g_{1}, g_{2}, \ldots, g_{l-1}$ together with some of the non core stable networks. Let $\tilde{g}_{l}$ be an adjacent network of $g_{l}$ such that $n\left(\tilde{g}_{l}, g_{1}\right) \geq n\left(g_{l}, g_{1}\right)$. Since $g_{l}$ is core stable and $\tilde{g}_{l}$ is adjacent, $r\left(g_{l}, \tilde{g}_{l}\right)=1$ and $\tilde{g}_{l}$ is non core stable. By Lemma 1, there exists a finite simultaneous improving path $\bar{p}=\left\{\tilde{g}_{l}, \ldots, \bar{g}\right\}$ of distinct networks such that $\bar{g}$ is core stable and $n\left(\bar{g}, g_{1}\right) \geq n\left(\tilde{g}_{l}, g_{1}\right)+1$. Recall that no core stable network in $\left\{g_{l+1}, \ldots, g_{k}\right\}$ is strictly closer to $g_{1}$ than $g_{l}$. Thus, $\bar{g}=g_{i} \in\left\{g_{1}, \ldots, g_{l-1}\right\}$.

Case 1: Except for $\bar{g}$, none of the networks on path $\bar{p}$ is connected to the existing $g_{1}$-subtree.

We add the directed path

$$
g_{l}, \underbrace{\tilde{g}_{l}, \ldots, g_{i}}_{\text {path } \bar{p}}
$$

to the existing $g_{1}$-subtree. By definition of $\bar{p}$ the resulting graph is a $g_{1}$-subtree of resistance $l-1$ that contains $g_{1}, g_{2}, \ldots, g_{l}$ together with some non core stable networks.

Case 2: Some network on path $\bar{p}$ different from $\bar{g}$ is connected to the existing $g_{1}$-subtree.

Let $g^{*}$ be the first network on path $\bar{p}$ that is connected to the existing $g_{1}$-subtree. We now only add the directed path $g_{l}, \tilde{g}_{l}, \ldots, g^{*}$ to the existing $g_{1}$-subtree. Since $\bar{p}$ is a path of distinct networks we obtain a $g_{1}$-subtree of resistance $l-1$ that contains $g_{1}, g_{2}, \ldots, g_{l}$ together with some non core stable networks.

After $k-1$ steps we have constructed a $g_{1}$-subtree of resistance $k-1$ that contains all core stable networks together with some non core stable networks.

Finally, by Lemma 1, we can connect any remaining (non core stable) network that is not connected to the $g_{1}$-subtree through a zero resistance path (as in Case 2, paths have to be adjusted if they contain already connected networks).

\footnotetext{
${ }^{3}$ Such a $\tilde{g}_{2}$ can be obtained by breaking a link in $g_{2}$ that does not exist in $g_{1}$ or adding a link in $g_{2}$ that exists in $g_{1}$ but not in $g_{2}$.
} 
Hence, we have constructed a $g_{1}$-tree with resistance $k-1$. As at least one mutation is needed to connect two core stable networks, $g_{1}$ has resistance $k-1$.

Claims 1, 2, and 3 establish the theorem.

\section{References}

Chung, K.-S. (2000): "On the Existence of Stable Roommate Matchings." Games and Economic Behavior, 33: 206-230.

Diamantoudi, E., Miyagawa, E., and Xue, L. (2004): "Random Paths to Stability in the Roommate Problem." Games and Economic Behavior, 48: 18-28.

Gale, D. and Shapley, L. S. (1962): "College Admissions and the Stability of Marriage." American Mathematical Monthly, 69: 9-15.

Gusfield, D. and Irving, R. W. (1989): The Stable Marriage Problem: Structure and Algorithms. The MIT Press, Cambridge.

Jackson, M. O. and Watts, A. (2002): "The Evolution of Social and Economic Networks." Journal of Economic Theory, 106: 265-295.

Roth, A. E. and Sotomayor, M. A. O. (1990): Two-Sided Matching: A Study in Game-Theoretic Modeling and Analysis. Cambridge University Press, Cambridge.

Roth, A. E. and Vande Vate, J. (1990): "Random Paths to Stability in Two-Sided Matching." Econometrica, 58: 1475-1480.

Tan, J. (1991): "A Necessary and Sufficient Condition for the Existence of a Complete Stable Matching." Journal of Algorithms, 12: 154-178. 